\title{
CORRESPONDENCE
}

\section{AGE OF METAMORPHISM OF MOINE SCHISTS}

SIR,--Measurements of geological age have been carried out on a number of pelitic Moine schists and gneisses using the potassium-argon method. These rocks, though quite similar mineralogically, from widely separated localities throughout the Highlands of Scotland, were made available from the collection of the Geological Survey of Great Britain (Edinburgh Office). All yielded samples of fresh mica, mainly biotite, formed during the metamorphism. Measurements were made on these micas. Details of the localities are given in Table 1 .

TABLE 1

\begin{tabular}{|c|c|c|c|c|}
\hline \multirow{2}{*}{$\begin{array}{l}\text { Geol. } \\
\text { Surv. } \\
\text { No. }\end{array}$} & \multicolumn{2}{|c|}{ Map } & \multirow{2}{*}{ County } & \multirow{2}{*}{ Locality } \\
\hline & $1 \mathrm{in.}$ & $6 \mathrm{in.}$ & & \\
\hline U 1368 & 43 & $177 \mathrm{NE}$. & Argyll & 400 feet SW. of where river leaves \\
\hline R 83 & 52 & $25 \mathrm{SE}$. & Argyll & $\begin{array}{l}\text { Near H.W.M. on east side of } \\
\text { small bay } 990 \text { yards S. } 37^{\circ} \text { W. of } \\
\text { Glenmore Bridge, Ardnamur- } \\
\text { chan. }\end{array}$ \\
\hline S 1716 & 52 & $157 \mathrm{NE}$. & Inverness & $\begin{array}{l}\text { NE. corner of Lochan Bad na } \\
\text { Sgitheiche } 850 \text { yards E. } 28^{\circ} \mathrm{S} \text {. } \\
\text { of } \triangle 52 \text { Ard Molach, Moidart. }\end{array}$ \\
\hline U 2228 & 71 & $77 \mathrm{SE}$. & Inverness & $\begin{array}{l}480 \text { yards SSE. of Eilean A } \\
\text { Mhiuneil, Loch Hourn. }\end{array}$ \\
\hline V 261 & 82 & $84 \mathrm{NE}$. & Ross & $\begin{array}{l}\text { Burn a few yards above wood } \\
\frac{3}{4} \text { mile NE. of Achnasheen. }\end{array}$ \\
\hline V 1127 & 109 & $46 \mathrm{NW}$. & Sutherland & $\begin{array}{l}\text { Coire nam Mang, } 6 \frac{3}{4} \text { miles NW. } \\
\text { of Kinbrace. }\end{array}$ \\
\hline V 1398 & 74 & $47 \mathrm{NW}$. & Inverness & $\begin{array}{l}\text { On hill slope } \frac{5}{8} \text { mile } \text { ENE. } \\
\text { of Coignnafeuinternich, River } \\
\text { Findhorn } 8 \frac{1}{2} \text { miles above } \\
\text { Tomatin. }\end{array}$ \\
\hline
\end{tabular}

Argon was extracted from the micas by fusing them without any flux, in a molybdenum crucible. The mixture of evolved gases which included the argon was purified using red hot titanium sponge, which has the property of being able to absorb large quantities of certain gases and retain them on cooling to room temperature. Argon is not taken up in this way and was further cleansed by absorbing it on to active charcoal, then pumping on this for about half an hour to remove traces of hydrogen. After repeated cleanings the total volume of argon was measured using a McLeod gauge.

Potassium analyses were carried out using the flame photometer, each sample being subjected to six separate potassium determinations. Each determination involved thirty flame photometer readings, the figure for each determination was obtained from the average of all thirty photometer readings, and the values quoted in the following table are in each case the average of all six done in this manner. $\mathrm{K}_{2} \mathrm{SO}_{4}$ standards were used to calibrate the photometer.

Using the mass spectrometer, the $\mathrm{A}^{40} / \mathrm{A}^{36}$ ratios of argon extracted from the micas were determined, and used to find the percentage contamination of the sample by atmospheric argon. This was done by comparing the isotopic ratio of the sample with that of argon obtained from the atmosphere.

The two constants used in the calculations are $\lambda \varepsilon$ the electron decay 
constant, here assumed to be $0.585 \times 10^{-10} \mathrm{yr}^{-1}$ and $\lambda B$ the $B^{-}$emission decay constant $4.76 \times 10^{-10} \mathrm{yr}^{-1}$.

The results are summarized in Table 2.

TABLE 2

\begin{tabular}{|c|c|c|c|c|c|c|}
\hline $\begin{array}{l}\text { Specimen } \\
\text { No. }\end{array}$ & $\begin{array}{l}\text { Analysis } \\
\text { Ref. No. }\end{array}$ & $\begin{array}{l}\text { Wt. of } \\
\text { sample } \\
\text { loaded } \\
\text { (gm.) }\end{array}$ & $\underset{\%}{\mathrm{~K}_{2} \mathrm{O}}$ & $\begin{array}{l}\text { Total } \\
\text { vol. of } \\
\text { argon } \\
\left.\left(\mathrm{mm}^{3}\right)^{3}\right)\end{array}$ & $\begin{array}{l}\text { Atmo- } \\
\text { spheric } \\
\text { contamina- } \\
\text { tion } \%\end{array}$ & $\begin{array}{l}\text { Apparent } \\
\text { age, } \\
\text { million } \\
\text { years }\end{array}$ \\
\hline U 1368 & $\mathrm{KA} / 30$ & $6 \cdot 0013$ & $8 \cdot 32$ & 0.847 & 7 & 429 \\
\hline R $\quad 83$ & $\mathrm{KA} / 48$ & $8 \cdot 5126$ & $8 \cdot 67$ & $1 \cdot 220$ & 4 & 434 \\
\hline S 1716 & $\mathrm{KA} / 45$ & $7 \cdot 2330$ & $7 \cdot 99$ & 0.990 & 7 & 431 \\
\hline U 2228 & $\mathrm{KA} / 2$ & 6.0544 & $6 \cdot 82$ & 0.668 & 2 & 434 \\
\hline V 261 & $\mathrm{KA} / 33$ & $7 \cdot 6398$ & $7 \cdot 36$ & $1 \cdot 032$ & 14 & 426 \\
\hline V 1127 & $\mathrm{KA} / 31$ & $8 \cdot 1040$ & $8 \cdot 50$ & $1 \cdot 20$ & 7 & 441 \\
\hline V 1398 & $\mathrm{KA} / 25$ & $5 \cdot 1634$ & $7 \cdot 55$ & 0.632 & 2 & 434 \\
\hline
\end{tabular}

Average $433 \pm 8$ (range of extremes).

Errors in these apparent ages introduced by the experimental procedure are believed not to be more than \pm 5 per cent.

These results indicate that the Moine Series of Scotland was subjected to regional metamorphism during Silurian (Holmes, 1959) times. Their consistency suggests that they have not since then undergone any disturbances, apart from localized intrusions, that have resulted in the serious loss of radiogenic argon from the micas formed as a result of this metamorphism. The existence of any previous episodes of regional metamorphism has not been proved or disproved by this work, neither has information been obtained on the actual age of the Moine sediments themselves.

Three hypotheses regarding the age of metamorphism, based on geological evidence, have been advanced (Phemister, 1948), namely, (a) Lewisian, (b) post-Lewisian but pre-Torridonian, (c) Caledonian. Much of present-day opinion is in favour of the view $(c)$, which these results support.

This is part of a project sponsored by the Department of Scientific and Industrial Research. I am indebted to the Royal Dutch Shell Oil Company for a studentship.

Department of Geodesy and Geophysics,

JoHn A. Miller.

CAMBRIDGE.

29 th September, 1960.

\section{REFERENCES}

Holmes, A., 1959. Trans. Edin. Geol. Soc., vol. 17, part 3, pp. 183-216.

Phemister, J., 1948. British Regional Geology. Scotland. The Northern Highlands (Second Edition). H.M. Stationery Office.

\section{AGE OF MOUNTSORREL GRANITE}

SIR,-The granite or granodiorite of Mountsorrel, situated some seven miles to the north of Leicester, England, is a large intrusive boss more than a mile in diameter, and projects through the Trias to give a series of isolated outcrops. Two varieties of this coarsely-crystalline rock exist and are distinguished by their pink and grey feldspars.

The age of this intrusion has long been in doubt. It is older than the 